\title{
TERAPI DALAM MENINGKATKAN STATUS GIZI PADA PASIEN SIROSIS HEPATIS
}

\author{
Resa Nirmala Jona ${ }^{1}$, Arlies Zenitha Victoria ${ }^{2}$ \\ Program Studi D-3 Keperawatan STIKES Telogorejo Semarang \\ Email: resa@stikestelogorejo.ac.id
}

\begin{abstract}
ABSTRAK
Malnutrisi merupakan komplikasi yang terkenal pada pasien dengan sirosis hepatis. Penurunan nilai kekuatan genggam berhubungan dengan malnutrisi dan dianggap sebagai parameter terpercaya yang mencerminkan hilangnya massa otot. Kepatuhan pasien dalam pemenuhan nutrisi yang tepat sangat diperlukan untuk sapat meningkatkan status gizi pasien, sehingga diperlukan perubahan perilaku (changes behavior). Salah satu jenis terapi dengan menggunakan pendekatan perilaku untuk mengatasi masalah ketidakpatuhan adalah Cognitive Behavior Therapy (CBT), yang merupakan salah satu bentuk psikoterapi yang mengubah pikiran negatif menjadi pikiran positif. Tujuan: Penelitian ini bertujuan untuk mengetahui Efektivitas Cognitive Behavior Therapy (CBT) dalam meningkatkan status gizi pada pasien sirosis hepatis. Jenis penelitian yang digunakan adalah penelitian quasi eksperimental pada pasien sirosis hepatis dengan kriteria child pugh A dan B, pemilihan sampel dengan cara purposive sampling dan dibagi dalam kelompok intervensi 34 responden dan kelompok kontrol 34 responden. Normalitas data diuji menggunakan Shapiro wilk, dilanjutkan dengan uji beda menggunakan Paired $T$ Test. Didapatkan nilai pre-post pada kelompok intervensi $\mathrm{p}=0,000$. Pengukuran efektivitas dihitung dengan rumus menurut Cohen's. Didapatkan nilai Effect Size (ES) CBT terhadap status gizi adalah 0,7 (efek sedang). Simpulan dari peneliian ini Cognitive Behavior Therapy (CBT) efektif dalam meningkatkan status gizi pada pasien sirosis hepatis.
\end{abstract}

Kata Kunci : Terapi, Status Gizi, Sirosis Hepatis

\section{PENDAHULUAN}

Sirosis hepatis menjadi penyebab ketujuh kematian di dunia. Sebanyak 25.000 orang meninggal per-tahun akibat sirosis hepatis (Suratun \& Lusianah, 2010). World Health Organization (WHO) mengemukakan bahwa pada tahun 2011 tercatat sebanyak 738.000 pasien meninggal akibat sirosis hepatis (Kementrian Kesehatan, 2014). WHO memperkirakan lebih 2 milyar penduduk dunia telah terinfeksi virus hepatitis $B$, dimana 378 juta atau $4,8 \%$ terinfeksi yang bersifat carier kronis dengan angka kematian 620,000 jiwa setiap tahun. Lebih dari 4,5 juta kasus infeksi baru virus hepatitis $B$ terjadi setiap tahun, dan satu per empat dari kejadian kasus tersebut berkembang menjadi penyakit hati sirosis hepatis dan karsinoma hepatoseluler primer (Kementrian Kesehatan, 2014; Ott, Stevens, Groeger, \& Wiersma, 2012).

Sirosis hepatis merupakan tahap akhir penyakit hati (Suratun \& Lusianah, 2010). Malnutrisi sering terjadi pada pasien dengan penyakit hati, prevalensi yang didapatkan yaitu $50 \%-90 \%$ di antara pasien sirosis (Cheung, Lee, \& Raman, 2012). Malnutrisi menyebabkan kelainan sensori-motor dan pengecilan otot yang bervariasi pada tiap tahapannya. Kekuatan genggam diakui

\section{*Corresponding Author :}

Resa Nirmala Jona

Program Studi D-3 Keperawatan

STIKES Telogorejo Semarang

Email: resa@ @tikestelogorejo.ac.id 
sebagai alat yang berguna untuk mengevaluasi kekuatan otot serta disarankan sebagai metode untuk mendeteksi kekurangan gizi di bidang klinik. Kekuatan genggaman adalah salah satu cara untuk menilai kapasitas fungsional, suatu pengukuran kekuatan otot tangan dan lengan yang dinyatakan dalam kilogram atau newton sesuai dengan kekuatan memeras atau menjepit dengan alat handgrip dynamometer. Penurunan nilai kekuatan genggam berhubungan dengan malnutrisi dan dianggap sebagai parameter terpercaya yang mencerminkan hilangnya massa otot (Silva et al., 2015).

Kepatuhan pasien dalam pemenuhan nutrisi yang tepat sangat diperlukan untuk meningkatkan status nutrisi, sehingga diperlukan perubahan perilaku (changes behavior). Salah satu jenis terapi dengan menggunakan pendekatan perilaku untuk mengatasi masalah ketidakpatuhan adalah Cognitive Behavior Therapy (CBT), merupakan salah satu bentuk psikoterapi yang mengubah pikiran negatif menjadi pikiran positif (Meichenbaum, 2009). Keunggulan dari terapi ini adalah menggali kemampuan seseorang untuk bereaksi secara adaptif dalam menghadapi masalah atau situasi sulit dalam setiap fase hidupnya (Beck, 2006).

Tujuan dari penelitian ini adalah untuk mengetahui efektifitas Cognitive Behavior Therapy (CBT) terhadap status gizi pada pasien sirosis hepatis.

\section{METODE PENELITIAN}

Penelitian ini menggunakan rancangan penelitian Quasy Experiment (eksperimen semu) dengan pendekatan Pre and post test control group design. Pada penelitian ini responden akan dibagi dalam dua kelompok, yaitu kelompok eksperimen dan kelompok kontrol. Kelompok intervensi

\section{*Corresponding Author :}

Resa Nirmala Jona

Program Studi D-3 Keperawatan

STIKES Telogorejo Semarang

Email: resa@stikestelogorejo.ac.id diberikan Cognitive Behavior Tehrapy (CBT), dan kelompok kontrol tidak diberikan perlakuan (usual care).

Populasi dalam penelitian ini adalah semua pasien sirosis hepatis yang mengalami rawat jalan. Jumlah sampel yang dibutuhkan untuk penelitian ini adalah 68 respponden dengan distribusi 34 untuk kelompok intervensi dan 34 untuk kelompok kontrol. Teknik pengambilan sampel dalam penelitian ini menggunakan metode non probability sampling dengan cara purposive sampling.

Adapun yang termasuk kriteria inklusi pada penelitian ini adalah pasien sirosis hepatis dengan kriteria child pugh A dan B, pasien sirosis hepatis di ruang rawat jalan yang bertempat tinggal di wilayah semarang (untuk kelompok intervensi), pasien berusia 17 - 55 tahun, pasien dapat berkomunikasi, pasien tidak mengalami gangguan pendengaran, pasien bersedia menjadi responden dan kriteria eksklusinya adalah tidak mengikuti sesi CBT secara lengkap.

Penelitian ini menggunakan uji Paired T-Test untuk membandingkan nilai pre-test dan post test pada masing-masing kelompok. Penilaian status gizi dengan mengukur kekuatan genggam tangan, menggunakan alat handgrip dynamometer dan lembar observasi.

\section{HASIL PENELITIAN DAN PEMBAHASAN}

Berdasarkan hasil uji kesetaraan karakteristik responden yang meliputi usia, jenis kelamin, tingkat pendidikan dan pekerjaan pada kelompok intervensi dan kelompok kontrol menunjukkan adanya homogenitas, dengan nilai $(p>0,005)$.

1. Usia

Berdasarkan data usia responden, distribusi data pada kelompok intervensi 
dan kelompok kontrol sebagian besar responden berusia 46-55 tahun. Pada kelompok kontrol sebanyak $61,8 \%$ dan kelompok intervensi sebanyak $58,8 \%$.

Hal ini sesuai dengan hasil penelitian Jeffrey yang menyatakan bahwa jumlah penderita sirosis hepatis terbanyak pada usia $>40$ tahun (Jeffrey $T$. Parsons, Sarit A. Golub, Elana Rosof, \& Catherine Holder, 2009). Hasil Riset Kesehatan Dasar (Riskesdas) juga menunjukkan bahwa data karakteristik prevalensi sirosis hepatis tertinggi terdapat pada kelompok umur 45-54 dan 65-74 tahun (Kementrian Kesehatan, 2014).

Penderita sirosis hati semakin banyak dijumpai seiring dengan bertambahnya usia. Sirosis hati adalah penyakit hati kronis atau menahun. Progresi dari kerusakan sel hati menuju sirosis dapat muncul dalam beberapa minggu sampai dengan bertahun-tahun. Oleh karena itu, infeksi virus yang terjadi di masa muda dapat menunjukkan manifestasi sebagai sirosis hati pada dekade yang lebih lanjut (Tambunan, Mulyadi, \& Ibnu, 2015).

2. Pendidikan

Berdasarkan karakteristik pendidikan responden, distribusi data pada kelompok intervensi jumlah responden paling banyak adalah berpendidikan sekolah dasar. Hal ini sesuai dengan hasil penelitian yang dilakukan oleh Corral F. bahwa, dilaporkan bahwa insiden sirosis hati per 100.000 pria adalah $88,3 \%$ di antara pria tanpa pendidikan, $52,6 \%$ di antara mereka yang memiliki pendidikan dasar, $28,8 \%$ di antara pria dengan pendidikan menengah, dan $14,9 \%$ di antara mereka dengan pendidikan universitas (Corral, Cueva, \& Yépez, 2001).

\section{*Corresponding Author :}

Resa Nirmala Jona

Program Studi D-3 Keperawatan

STIKES Telogorejo Semarang

Email: resa@ @tikestelogorejo.ac.id
Pendidikan seseorang akan mempengaruhi pola pikir kognitif dikarenakan dipengaruhi oleh faktor informasi yang didapatkan selama masa pendidikan dan pengalaman yang dialami seseorang. Sesorang dengan pendidikan tinggi biasanya cenderung memiliki pemahaman yang lebih baik tentang penyakit dalam hal penyebab, pilihan pengobatan dan prognosis (Suwistianisa \& Huda, 2015).

3. Pekerjaan

Berdasarkan karakteristik pekerjaan, sebagian besar responden bekerja sebagai wiraswasta dan pekerja swasta. Hal ini sesuai dengan hasil penelitian Mutia yang menyebutkan bahwa responden yang terbanyak adalah pekerja swasta. Hal ini dapat disebabkan karena kemungkinan adanya paparan penyakit di tempat kerja. Penyebab sirosis hati terbanyak adalah riwayat penyakit hepatitis. Penyebab yang lain yaitu alkohol, diabetes mellitus, kardiaksirosis, dan sirosis hati non B-non C (Mutia, 2017).

4. Jenis Kelamin

Berdasarkan karakteristik jenis kelamin, sebagian responden berjenis kelamin laki-laki dengan jumlah 22 responden $(64,7 \%)$ pada kelompok intervensi dan 24 responden (70,6\%) pada kelompok kontrol. Hal ini sesuai dengan hasil penelitian yang dilakukan oleh Tambunan bahwa bahwa jumlah responden terbanyak berjenis kelamin laki-laki dibandingkan perempuan, dengan perbandingan 2,3: 1 (Tambunan et al., 2015).

Kecenderungan ini belum diketahui secara pasti penyebabnya. Laki-laki lebih banyak menderita sirosis hati kemungkinan karena mereka lebih sering 
terpapar dengan sejumlah agen penyebab sirosis hati, seperti virus hepatitis dan alkohol. Selain itu juga dapat dikarenakan minimnya penggunaan sumber-sumber layanan kesehatan, sehingga mereka yang menderita sirosis hati kurang terdeteksi dan tidak terlaporkan (Mutia, 2017).

Perbedaan status gizi sebelum dan sesudah diberikan Cognitive Behavior Therapy (CBT) pada kelompok intervensi dan kelompok kontrol

Hasil uji beda status gizi responden menunjukkan bahwa terdapat perbedaan status gizi yang signifikan pada kelompok intervensi saat pre test dan post test, dengan demikian dapat disimpulkan bahwa status gizi pada kelompok intervensi naik secara signifikan setelah diberikan CBT, sedangkan pada kelompok kontrol menunjukkan bahwa tidak terdapat perbedaan status gizi saat pre test dan post test. Dapat disimpulkan bahwa status gizi pada kelompok kontrol tidak bermakna setelah diberikan usual care di Rumah Sakit.

Setiap individu membutuhkan asupan zat gizi yang berbeda antar individu, hal ini tergantung pada usia orang tersebut, jenis kelamin, aktivitas tubuh dalam sehari, berat badan, dan lainnya. Status gizi seseorang tergantung dari asupan gizi dan kebutuhannya, jika antara asupan gizi dengan kebutuhan tubuhnya seimbang, maka akan menghasilkan status gizi yang baik (Harjatmo, Par'i, \& Wiyono, 2017)

Salah satu aspek Cognitive Behavior Therapy (CBT) adalah merubah pola pikir negatif menjadi positif sehingga perilaku maladaptif yang timbul akibat pola pikir yang salah juga akan berubah menjadi perilaku yang adaptif (Beck, 2006). Seseorang yang patuh akan diet yang telah dianjurkan, akan berdampak pada peningkatan atau perbaikan status gizi (Cahyati, 2015).

\section{Efektifitas Cognitive Behavior Therapy (CBT) terhadap status gizi pada kelompok intervensi dan kelompok control}

Untuk mengetahui besar pengaruh (effect size) CBT terhadap status gizi pada kelompok intervensi maka dilakukan penghitungan effect size. Penghitungan besar pengaruh CBT tersebut menggunakan rumus Cohen's sebagai berikut:

$$
\begin{array}{r}
S_{g a b}=\sqrt{\frac{(n 1-1) S_{1}^{2}+(n 2-1) S_{2}^{2}}{n 1+n 2-2}} \\
=\sqrt{\frac{S_{g a b}}{34+34-2}} \\
=7,58 \quad d=\frac{X_{1}-X_{2}}{S_{g a b}} \\
d=\frac{38,74-32,85}{7,58}
\end{array}
$$

Keterangan:

$d \quad=$ nilai effect size

$S_{g a b}=$ standar deviasi gabungan

$X_{1}=$ rerata kelompok intervensi

$X_{2}=$ rerata kelompok kontrol

$n 1=$ besar sampel kelompok intervensi

$n 2=$ besar sampel kelompok kontrol

$S_{1}=$ standar deviasi kelompok intervensi

$S_{2}=$ standar deviasi kelompok kontrol

Perhitungan di atas menunjukkan nilai effect size CBT terhadap kepatuhan diet yaitu sebesar 0,7. Berdasarkan kriteria nilai

*Corresponding Author :

Resa Nirmala Jona

Program Studi D-3 Keperawatan

STIKES Telogorejo Semarang

Email: resa@ @stikestelogorejo.ac.id 
Cohen's, nilai $(0,5-0,8)$ memiliki besar efek yang sedang. Dapat diartikan bahwa CBT memiliki efek yang sedang dalam meningkatkan status gizi pada pasien sirosis hepatis sebanyak $43 \%$.

Nilai besar efek ini belum memiliki nilai tinggi dalam meningkatkan status gizi pada pasien sirosis hepatis. Hal ini dapat disebabkan kurang lamanya waktu evaluasi perubahan status gizi setelah diberikan CBT. Berdasarkan penelitian yang dilakukan oleh Mutia, menyebutkan bahwa untuk mengetahui perubahan status gizi seseorang dibutuhkan waktu antara 1-3 bulan (Mutia, 2017). Akan tetapi, CBT menunjukkan dampak yang positif dalam meningkatkan skor kekuatan genggam tangan (handgrip strength) pada kelompok intervensi.

Cognitive Behavioral Therapy (CBT) sebagai psikoterapi yang berfokus pada masalah dibuat untuk mengurangi gejala dan membangun kepercayaan bahwa seseorang memiliki kontrol pikiran, kepercayaan, perilaku dan keterampilan untuk membantu pasien selama terapi diet. Peran CBT dalam terapi diet sirosis memberikan dampak positif, sehingga dapat meningkatkan atau memperbaiki status gizi pada pasien yang akan menjalani perawatan (Sulistyowati, Respati, \& Nasrudin, 2016). Proses terjadinya dampak positif setelah CBT pada pasien sirosis hepatis pada penelitian ini hanya dapat dilihat secara fisik yaitu dari peningkatan status gizi yang dapat dilihat dari meningkatkan kekuatan genggam tangan (handgrip strength), akan tetapi penelitian belum dapat hasil perubahan status gizi dalam istilah biomolekuler.

Pada penelitian ini, selain diberikan CBT, responden juga diberikan edukasi mengenai diet yang tepat untuk penderita sirosis hepatis. Pengetahuan merupakan modal awal bagi terbentuknya sikap yang akhirnya akan mengarah pada niat akan melakukan perbuatan atau bertindak. Berdasarkan

\section{*Corresponding Author :}

Resa Nirmala Jona

Program Studi D-3 Keperawatan

STIKES Telogorejo Semarang

Email: resa@ @stikestelogorejo.ac.id pernyataan tersebut, maka yang harus dilakukan pertama kali adalah memperbaiki pengetahuan pasien sehingga menumbuhkan keyakinan pada pasien yang akhirnya akan menimbulkan sikap yang baik. Seseorang dengan keyakinan yang baik akan keberhasilan terapi yang dijalani, maka akan meningkatkan kepatuhan pasien dalam menjalani terapi yang dilakukan (IImah, 2015). Seseorang yang patuh akan diet yang telah dianjurkan, akan berdampak pada peningkatan atau perbaikan status gizi. Hal ini sesuai dengan penelitian Cahyati bahwa ada hubungan kepatuhan diet dengan peningkatan status gizi (Cahyati, 2015)

\section{SIMPULAN}

Kepatuhan dalam menjalankan diet yang tepat akan dapat meningkatkan status gizi seseorang. Untuk meningkatkan kepatuhan, perlu dilakukan perubahan perilaku negatif menjadi positif dengan mengubah pikiran negatif menjadi positif pula. Cognitive Behavior Therapy (CBT) efektif dalam meningkatkan status gizi pada pasien sirosis hepatis, dengan memiliki besar efek 0,7 (efek sedang). Selain diberikan CBT, peneliti juga memberikan edukasi mengenai diet yang tepat untuk penderita sirosis hepatis, yang mana pengetahuan merupakan modal awal bagi terbentuknya sikap yang akhirnya akan mengarah pada niat untuk melakukan perubahan sikap. Hal ini perlu ditindaklanjuti oleh pihak rumah sakit bahwa CBT dan edukasi dapat menjadi salah satu tindakan keperawatan untuk meningkatkan status gizi pasien khususnya pasien sirosis hepatis.

\section{DAFTAR PUSTAKA}

\section{Beck, A. (2006). COGNITIVE BEHAVIORAL} THERAPY Arron Beck ".

Cahyati, S. M. W. (2015). Hubungan 
Kepatuhan Diet dengan Status Gizi pada Penderita Diabetes Mellitus Tipe II di Dusun Karang Tengah Yogyakarta. Unisa Digital Library, 43.

Cheung, K., Lee, S. S., \& Raman, M. (2012). Prevalence and Mechanisms of Malnutrition in Patients With Advanced. YJCGH, 10(2), 117-125. https://doi.org/10.1016/j.cgh.2011.08.01 6

Corral, F., Cueva, P., \& Yépez, J. M. (2001). Limited education as a risk factor in cervical cancer. Natl Tumor Regist Soc Struggl against Cancer (Registro Nac Tumores; Soc Lucha contra el CáncerSOLCA). Quito; Ecuador, 30, 322.

Harjatmo, T. P., Par'i, H., \& Wiyono, S. (2017). Penilaian Status Gizi (Tahun 2017). Jakarta: Kementrian Kesehatan Republik Indonesia.

Ilmah, F. (2015). Kepatuhan Pasien Rawat Inap Dietdiabetes Mellitus berdasarkan Teori kepatuhan Niven. Jurnal Administrasi Kesehatan Indonesia, 3(1).

Jeffrey T. Parsons, P., Sarit A. Golub, P., Elana Rosof, P., \& Catherine Holder, B. (2009). Motivational Interviewing and Cognitive-Behavioral Intervention to Improve HIV Medication Adherence Among Hazardous Drinkers: A Randomized Controlled Trial, 46(4), 443-450.

Kementrian Kesehatan, R. (2014). infodatinhepatitis.pdf.

Meichenbaum, D. (2009). COGNITIVEBEHAVIORAL THERAPY.

Mutia, D. F. B. (2017). Penatalaksanaan dan edukasi pasien sirosis hati dengan varises esofagus. Intisari Sains Medis, 8 , 19-23.

\section{*Corresponding Author :}

Resa Nirmala Jona

Program Studi D-3 Keperawatan

STIKES Telogorejo Semarang

Email: resa@stikestelogorejo.ac.id
Ott, J. J., Stevens, G. A., Groeger, J., \& Wiersma, S. T. (2012). Global epidemiology of hepatitis B virus infection: New estimates of age-specific HBsAg seroprevalence and endemicity. Vaccine, $\quad 30(12), \quad 2212-2219$. https://doi.org/10.1016/j.vaccine.2011.1 2.116

Silva, M., Gomes, S., Peixoto, A., Torresramalho, P., Cardoso, H., Azevedo, R., ... Macedo, G. (2015). Nutrition in Chronic Liver Disease. GE Jornal Português de Gastrenterologia, 22(6), 268-276.

https://doi.org/10.1016/j.jpge.2015.06.0 04

Sulistyowati, S., Respati, S., \& Nasrudin, M. (2016). Effect of Cognitive Behavioral Therapy for Serotonin Level, 52(3), 231234.

Suratun, \& Lusianah. (2010). Asuhan Keperawatan Klien dengan Gangguan Sistem Gastrointestinal. Jakarta: Trans Info Media.

Suwistianisa, R., \& Huda, N. J. (2015). Faktor-Faktor Yang Mempengaruhi Tingkat Kepatuhan Diet Pada Pasien Kanker Yang Dirawat Di RSUD Arifin Achmad Provinsi Riau. JOM, 2, 2.

Tambunan, A., Mulyadi, Y., \& Ibnu, K. M. (2015). Karakteristik pasien sirosis hepatis. Journal FK Untan. 